\title{
Penerapan Metode Istihssan Pada Bidang Muâmalah Mâliyyah (Hukum Ekonomi Syariah)
}

\author{
Panji Adam \\ Fakultas Syariah Universitas Islam Bandung \\ Jalan Tamansari 24-26 Bandung \\ Correspondence email: panjiadam06@gmail.com
}

\begin{abstract}
Abstrak. Istihsan merupakan salah satu metode ijtihad yang diperselisihkan oleh para ulama ushul fikih, meskipun dalam kenyataannya, semua ulama mengguakannya secara praktis. Penetapan hukum dengan metode istihsan banyak dilakukan oleh ulama di kalangan Hanafiyyah dan Malikiyyah sehingga dalam sejarah ushul fikih, golongan Hanafiyyah dikenal sebagai golongan yang memakai istihlsan sebagai salah satu metode istinbâth al-ahkâm (penetapan hukum). Imam Syafi'i adalah ulama yang menolak istihhsan sebagai metode penetapan hukum Islam. Namun dalam praktiknya Imam Syafi'i pun menggunakan istihsan sebagai metode penetapan hukum Islam. Ilmu ushul fikih memiliki peran yang signifikan dalam memberikan kontribusi atas eksistensi hukum Islam khususnya bidang hukum ekonomi syariah. Metode penelitian yang dilakukan berdasarkan pendekatan secara yuridis normatif, Spesifikasi penelitian yang digunakan adalah deskriptif analitis, Jenis data yang dipergunakan dalam peneitian ini, yaitu data sekunder, metode pengumpulan data yang dipergunakan adalah studi kepustakaan dan Analisis terhadap data sekunder yang bersifat kualitatif. Hasil penelitian menunjukan bahwa bahwa istihsan merupakan salah satu metode istinbâth al-ahkâm, yang dapat dijadikan hujjah dan menjadi dalil syara' serta berfungsi dalam menentukan keabsahan suatu akad/transaksi dalam bidang hukum ekonomi syariah.
\end{abstract}

Kata Kunci: Istihsan; mazhab Hanafiyyah; mazhab Syafi'iyyah; Mu'amalah Maliyyah

\begin{abstract}
Istihsan is one of the ijtihad methods disputed by the scholars ushul fiqh, although in reality, all scholars use it practically. The establishment of the law by istihsan method is widely carried out by scholars among the Hanafiyyah and Malikiyyah so that in the history of ushul figh, the Hanafiyyah are known as the group that uses istihsan as one of the methods of istinbâth al-ahkâm (determination of the law). Imam Shafi'i is a cleric who rejects istihsan as a method of determining Islamic law. But in practice Imam Shafi'i also uses istihsan as a method of determining Islamic law. The science of ushul fikih has a significant role in contributing to the existence of Islamic law, especially in the field of Sharia economic law. Research method conducted based on normative juridical approach. The specification of research used is analytical descriptive, The type of data used in this research, namely secondary data, data collection method used is literature study and analysis of secondary data that is qualitative. The results showed that istihsan is one of the methods of istinbâth al-ahkâm, which can be used as an argument and a proof of syara' and serves in determining the validity of an agreement / transaction in the field of Sharia economic law.
\end{abstract}

Keywords: Istihsan; hanafiyyah sect; shafi'iyyah sect; Mu'amalah Maliyyah

\section{PENDAHULUAN}

Pembahasan tentang dalil-dalil metode penetapan hukum Islam dalam kajian ilmu ushul fikih dibagi menjadi dua bagian kelompok besar, yakni dalil-dalil yang disepakati (al-Adillah al-Muttafaq 'Alaiha) dan dalil-dalil yang diperselisihkan (al-Adillah al-Mukhtlaf Fîha).(Syawaluddin Hanafi, 2020)

Dalam kajian ilmu ushul fikih, hampir semua kitab-kitab ushul fikih menyebutkan bahwa metode ijtihad sering disebut dengan dalil-dalil syara' yang penggunaannya tidak disepakati oleh ulama sebagai pelengkap dari empat dalil syara' yang disepakati, yaitu Alquran, hadis, ijmak (konsensu) dan qiyâs (analogi).

Diantara dalil-dalil dalam metode penetapan hukum Islam yang masih bersifat mukhtalaf fih (diperselisihkan) kehujjahannya adalah istihsan. Sekalipun metode istihsan merupakan dalil syara yang tidak disepakati, namun dalam kenyataannya, semua ulama menggunakan istihsan dalam arti lughawi (etimologis), yaitu "berbuat sesuatu yang lebih baik".
Tetapi dalam pengertian istilahnya (yang biasa berlaku), para ulama ushul fikih terjadi perbedaan disebabkan oleh perbedaan dalam memahami serta memberikan definisi "istihsan" itu sendiri.

Istihsan secara konsep merupakan suatu kecendrungan untuk mengambil dan mengamalkan hukum karena dinilai sebagai hukum yang lebih baik bila dibandingkan dengan praktik yang berlaku dari hukum asal.(Chadzik, 2019) Istihsan merupakan dalil hukum Islam yang banyak digunakan dalam terminologi dan istinbâth hukum oleh dua Imam mazhab, yaitu Imam Malik dan Abu Hanifah. Bahkan Imam Malik menilai pemakaian istihsan hingga $90 \%$ dan seluruh ilmu fikih.(Bakhtiar Hasan, 2015)

Menurut mereka istihlsan dapat menjadi dalil syara'. Istihsan dapat menetapkan hukum yang berbeda dengan hukum yang ditetapkan oleh qiyâs atau umum nash. Tegasnya menurut mereka, istihsan dapat dijadikan sebagai dalil (hujjah). Al- Taftazani berpendapat bahwa istihssan adalah salah satu dan dalil- 
dalil yang disepakati oleh para ulama, karena istihsan didasarkan kepada nash, atau kepada ijma, atau kepada darurat, atau kepada qiyâs khafi.

Imam Syafiei merupakan salah satu ulama yang dengan tegas membatalkan tentang dalil Istihsan, karena itu ia menguraikannya dalam pasal tersendiri yang terdapat di dalam kitabnya yaitu al-Umm dengan judul "Ibthal al-Istihsan" (pembatalan dalil istihsan).(Kadenun, 2018). Imam al-Syafi'i menolak metode istihsan karena memandangnya sebagai cara istinbâth hukum dengan hawa nafsu dan mencari enaknya saja.

Dalam setiap aspek hukum yang terkait dengan kajian muamalah maliyah (hukum ekonomi syariah), maka keterlibatan serta kontribusi para fukaha (ahli hukum Islam) menjadi penting untuk berperan dalam hal melakukan ijtihad guna memberikan solusi terhadap permasalahan ekonomi dan bisnis yang muncul, baik pada skala makro maupun mikro.

Dalam rangka mengembangkan ekonimi dan bisnis syariah serta merespon kondisi perekonomian hari inipara ulama harus cermat serta kreatif dalam mengembangkan hukum Islam khsusunya di bidang hukum ekonomi syariah dengan menggunakan metode istinbâth hukum yang relevan. Istiḩsan yang dikembangkan dan dicetuskan oleh Imam Hanafi yang mewakili kelompok rasionalis, tentu metode ini mempunyai implikasi yang sangat signifikan terhadap pengembangan hukum ekonomi syariah. Dikarenakan istihsan yang lebih mengedepankan rasionalitas dipandang mempunyai porsi yang sangat lebih dibandingakan dengan metode yang mengedepankan teks belaka.(Nur'aini, 2020)

Dengan demikian perlu dilakukan sebuah penelitian dalam rangka mengidentifikasi penerapan metode istihsan dalam bidang mu'âmalah mâliyyah atau hukum ekonomi syariah guna memberikan kepastian hukum terkait kebasahan sebuah akad/transaksi berlandaskan teori ilmu ushul fikih.

\section{METODE}

Metode penelitian yang dilakukan berdasarkan pendekatan secara yuridis normatif, yaitu dengan mengkaji atau menganalisis data sekunder yang berupa bahan-bahan hukum sekunder dengan memahami hukum sebagai perangkat peraturan atau norma positif di dalam perundang-undangan yang berlaku, jadi penelitian ini dipahami sebagai penelitian kepustakaan, yaitu penelitian terhadap bahan sekunder.(Soerjono Soekanto \& Sri Mamudji, 1985)

Spesifikasi penelitian yang digunakan adalah deskriptif analitis, yaitu penelitian untuk menggambarkan masalah yang ada pada masa sekarang (masalah yang aktual), dengan mengumpulkan data, menyusun, mengklasifikasikan, menganalisis, dan menginterpretasikan. Deskriptif bertujuan memaparkan data hasil pengamatan tanpa pengujian hipotesishipotesis.(Adi, 2004)

Jenis data yang dipergunakan dalam peneitian ini, yaitu data sekunder, yaitu kitab-kitab atau buku-buku literatur ushul fikih yang relevan dengan fokus penelitian. Metode analisis data yang digunakan dalam penelitian ini adalah metode kualitatif. Analisis terhadap data sekunder yang bersifat kualitatif tersebut dilakukan dengan cara berlandaskan pada teori hukum ataupun doktrin hukum yang terdapat pada kerangka pikir, kemudian diterapkan secara deduktif terhadap fokus permasalahan.

\section{HASIL DAN PEMBAHASAN}

\section{Metode Istihsan dalam Literatur Ushûl Fikih}

Ali Hasab Allah menjelaskan bahwa yang dimaksud dengan istihsan secara etimologis adalah:

عد الثيء حسنا

"Memandang baik terhadap sesuatu".(Ali Hasab Allah, 1971)

Adapun pengertian istihlsan secara terminologis sebagaimana dikemukakan oleh Abd al-Wahab Khallaf adalah sebagai berikut:

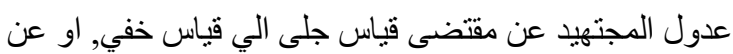

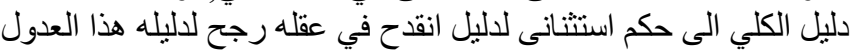
"Bepindahnya seorang mujtahid dari tuntutan qiyâs jaly kepada qiyâs khafy, atau dari dalil-dlail kully kepada hukum pengecualian (khusus) karena terdapat dalil yang menyebabkan mujtahid merubah pikirannya dan mementingan perpindahan"(Khallaf, 2013).

Merangkum berbagai pendapat para ahli ushul fikih mengenai definisi istihsan, Wahbah alZuhaili,(Wahbah al-Zuhaili, 2006) memberikan dua definisi, yaitu:

$$
\text { ترجيح قياس خفي على قياس جلي بناء على دليل }
$$

"Memakai qiyâs khafy dan meninggalkan qiyâs jaly karena terdapat petunjuk untuk itu"

$$
\text { دليل خاص يقتضاء مسالة جزئية من اصلى كلي, او قاعدة عامة, بناء على }
$$

"Hukum pengecualian dari kaidah-kaidah yang berlaku umum kerana ada petunjuk untuk hal tersebut".

Istihsan yang disebut pertama dikenal dengan istihsan qiyasi, sedangkan yang kedua disebut dengan istihlsan istisaiy. Istihssan qiyasi terjadi pada suatu kasus yang mungkin dilakukan padanya salah satu dari dua bentuk qiyâs, yaitu qiyâs jaly atau qiyâs khafy. Pada dasarnya jika dilihat dari kejalasan illat qiyâs jaly lebih lantas didahulukan atas qiyâs khafy. Dalam hal ini Imam 
Hanafi berpendapat: Jika qiyâs khafy lebih besar manfaatnya, maka qiyâs jaly itu boleh ditinggalkan dan yang dipakai qiyâs khafy praktik seperti inilah yang dikenal dengan istihsan qiyasi.

Para ulama ushul fikih menginformasikan bahwa lafadz istihsan terdapat dalam Alquran dan hadis Nabi. Dasar istihsan dalam Alquran adalah firman Allah Swt dalam surah al-Zumar (39) ayat 18 yang berbunyi:

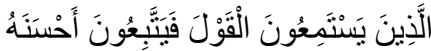

"Yang mendengarkan perkataan lalu mengikuti apa yang paling baik di antaranya..."

Ayat di atas menjadi landasan argumentasi mengenai ke-hujjah-an serta kebolehan menggunakan metode istihsan menurut kalangan ulama Hanafiyyah.(Habibullah, 2017)

dan Alquran surah al-'Araf (7) ayat 145 yang berbunyi:

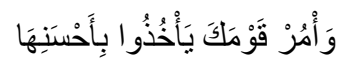

“,,dan perintahkanlah kaummu untuk berpegang kepada (perintahnya) dengan sebaik-baiknya...

Serta dalam hadis Nabi Muhammad Saw yang bersumber dari sahabat Ibn Mas'ud r.a sebagaimana diriwayatkan oleh Imam Ahmad Ibn Hanbal dalam Musnad-nya sebagai berikut:

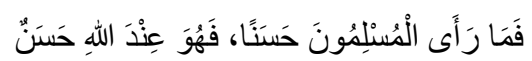

"Sesuatu yang menurut umat Islam baik, adalah baik di sisi Allah Swt”.(Hanbal, 2001)

Memperhatikan kehujjahan istihsan dan menggunakannya sebagai istinbâth al-ahkâm, memang menimbulkan iktilâf (perbedaban) di kalangan para ulama ushul. Imam Abu Hanifah sebagai seorang ulama yang menampilkan istihssan sebagai salah satu dalil hukum, tak pelak lagi mendapatkan serangan dan kritik yang hebat dari lawan-lawannya yang menolak istihsan sebagai dalil hukum.

Dalam literatur uhsul fikih diinformasikan bahwa dalam persoalan istihsan terdapat 2 (dua) pendpaat ulama, kelompok yang berhujjah dan menggunakan istihsan sebagai dalil hukum sebagaimana dinyatakan oleh Abd al-Wahab Khallaf ialah terdiri dari mazhab Hanafi, mazhab Maliki dan Mazhab Hanbali. Kelompok ini mengatakan bahwa:

$$
\text { انه دليل شرعي ثبت به الاحكام في مقابل ما يوجبه القياس او }
$$

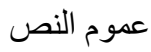

"Sesungguhnya (istihlsan) adalah salah satu dalil hukum syara' dan istihsan digunakan untuk menetapkan berbagai hukum ketika berlawaan dengan qiyâs atau kaidah nash umum yang berlaku”.(Khallaf, 2013)
Muhammad Abu Zahra menyebutkan bahwa bagi mazhab Hanafi dan Maliki penggunaan istihsan tidaklah keluar dari nash syara' dan Imam Abu Hanifah sendiri mengatakan bahwa istihsan merupakan bagian dari dalil syara' selain dari nash yang tertulis.(Muhammad Abu Zahrah, n.d.). Menurut Zaky al-Din Sya'ban, istihsan merupakan salah satu dasar istinbâth al-ahkâm dalam mazhab Hanafi dan mazhab Maliki (Zaky al-Din Sya'ban, 1965). Menurut mazhab Hanafi, istihsan sebenarnya semacam qiyâs, yaitu memenangkan qiyâs khafy atas qiyâs jaly atau mengubah hukumyang telah ditetapkan pada suatu kasus atau kejadian yang telah ditetapkan berdasarkan ketentuan umum kepada ketentuan khusus karena ada suatu kepentingan yang membolehkannya (Zulbaidah, 2016).

Sebagaimana dinyatakan di atas bahwa, banyak terdapat kata istihlsan dalam pembicaraan mazhab $\underline{\text { Hanafi }}$ dan mereke sering menjadikannya sebagai lawan qiyâs seraya berkata: qiyâs dapat menimbulkan keharaman dan istiḩsan bisa menimbulkan ibâhah (kebolehan). Maka mereka menjadikannya sebagai dalil syara' yang menentang dalil yang menyamainya dan mengadakan tarjih (pengunggulan) atasnya. Para penentang mereka telah menyangkal penamaan lafadz ini, karena mereka menganggapnya sebagai tasyri' tanpa dalil (Beik, 2003).

Tokoh yang sangat populer menentang istihsan sebagai hujjah dan dalil dalam istinbâth hukum adalah Imam Syafi'i. Sebagaimana dikutip oleh al-Ghazali, penolakan Syafi'i tercermin dalam pernyataannya yang sangat popouler seagai berikut:

$$
\text { قال الثافعي رضي الله عنه من استحسن فقد شرع }
$$

"Barangsiapa yang menggunakan istihsan maka ia telah membuat syariat" (Abu Hamid al-Ghazali, 1989).

Bahkan Imam Syafi'i dalam kitabnya al-Risâlah menyatakan dengan tegas sebagai berikut:

$$
\begin{aligned}
& \text { أنه لبس لأحد دون رسول الله أن يقول إلا بالاستدلال... و لا يقول بما }
\end{aligned}
$$

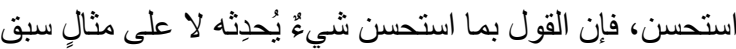

"Tidak seorang pun berhak selain Rasulullah menetapkan sesuatu hukum tanpa alasan (dalil) dan tidak seorang pun pantas menetapkan berdasarkan istihsan adalah membuat ketentuan baru yang tidak mempedomani ketentuan yang telah digariskan sebelumnya” (Muhammad Ibn Idris al-Syafi'i, 1940).

Pernyataan Imam Syafi'i di atas mengandung pengertian bahwa segala sesuatu harus mengacu kepada nash Alquran dan sunah, bukan dengan istihsan. Adapun alasan-alasan Imam Syafi'i menolak istihhsan sebagai hujjah, sebagaimana dijelaskan oleh Romi sebagai berikut: (1) Imam Syafi'i mengatakan bahwa sesungguhya syariat berdasarkan nash-nash Alquran, sunah dan qiyâs, bukan berdasarkan istihlsan; (2) menurut Syafi'i, banyak sekali ayat-ayat Alquran yang 
memerintahkan untuk menaati Allah dan Rasul-Nya dan melarang mengikuti hawa nafsu; (3) selainjutnya Syafi'i beralasan bahwa Nabi Saw tidak pernah menetapkan hukum dengan istihsan dan beliau tidak berbicara menurut hawa nafsunya saja; (4) Nabi Saw menolak para sahabat menggunakan istihsan, yaitu ketetapan sahabat yang didasarkan pada apa yan mereka pandang baik; (5) sesungguhnya istihsan itu tidak pasti dan tidak jelas serta tidak dapat dijadikan ukuran untuk membedakan yang hak dengan yang batil, sebagaimana layaknya qiyâs; dan (6) jika mujtahid dibolehkan menggunakan istihsan berarti ia tidak lagi berpegang kepada nash, tetapi hanya berhujah pada akal semata.(Romli, 1999)

Sebetulnya apabila dicermati secara jeli, alasanalasan yang dikemukakan Syafi'i di atas dalam rangka penolkannya terhadap kelompok yang menggunakan istihlsan, Hanafi, Maliki dan Hanbali, tidaklah seperti yang dibayangkan oleh Syafi'i, yaitu berdasarkan hawa nafsu saja, tetapi istihsan yang dilandasi oleh jiwa dan ruh nash syariat. Mazhab Maliki menggunakan istihsan bahwa pijakannya tidak keluar dari nash syariat, maka tetap berpijak pada landasan qiyâs, atsar, ijmâ', al-'urf dan al-dharûrah.

Perdebatan mengenai penggunaan istihsan didominasi oleh dua aliran, yaitu Hanafiyah dan Syafi'iyah. Oleh karena itu, dalam perdebatan tersebut lebih mengedepankan pendapat kedua aliran ini. Imam Ghazali mengutip pendapat ulama Hanafiyah sebagai berikut:

$$
\text { وقاستحسان مذائلون من أصحاب ابي حنيفة رضيل رضي الله عنه }
$$

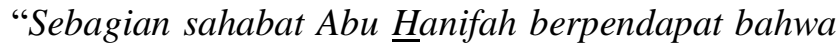
istihsan adalah suatu pendapat yang tidak ada dalilnya" (Abu Hamid al-Ghazali, 1989).

Terhadap pendapat tersebut, Imam al-Ghazali berkomentar sebagai berikut:

$$
\text { و هذا كفر ممن فاله وممن يجوز التمسك به و لا حاجة فيه إلى }
$$

"Ulama yang berpendapat demikian adalah kafir; dan ulama yang membolehkan berpegang kepad apendapat yang demikian juga kafir; dan ulama yang tidak membutuhkan dalil juga kafir"..(Abu Hamid alGhazali, 1989)

Selanjutnya Imam al-Ghazali mengutip pendapat ulama lainnya yang mengatakan bahwa istihsan adalah:

$$
\text { وقال قائلون هو معنى خفي تضيق العبارة عند }
$$

"Makna tersembunyi yang terdapat kesempitan untuk menjelaskan”.(Abu Hamid al-Ghazali, 1989)

Terhadap pendapat tersebut, Imam al-Ghazali berkomentar sebagai berikut:
و هذا أيضا هوس فإن معاني الثـارع إذا لاحت في العقول انطلقت الألسن

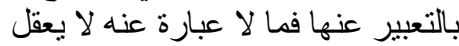

"Ini adlaah mengacaukan pula; sesungguhnya perintah-perintah Allah dapat dimengerti dengan akal; maka dengan mudah manusia dapat memahaminya; suatu (ketetepan syara') yang tidak dapat dimengerti adalah tidak masuk akal".(Abu Hamid al-Ghazali, 1989)

Tampaknya, kalangan ulama Syafi'iyah telah melakukan klarifikasi istihssan. Imam al-Ghazali setelah menguraikan pendapat Imam al-Karkhi tentang istihsan, mengomentari pendapat al-Karkhi al- $\underline{H}$ anafi tersebut. dalam uraiannya, al-Karkhi membedakan istihssan kedalam empat kemungkinan, pertama, mengikuti hadis dan meninggalkan qiyâs; kedua, mengikuti (mengutamakan) qawl (pendapat) sahabat atas qiyâs; ketiga, mengikuti adat yang berlaku di masyarakat dan keempat, mengikuti makna yang tersembunyi.(Mubarok, 2002)

Dua macam yang pertama (mengikuti hadis dan qawl sahabat dengan mengabaikan qiyâs), sejalan dengan aliran Syafi'iyah. Secara implisit, Imam alGhazali menyebutkan sebagai istihsan shahㅡhㅡ; sedangkan dua bagian terakhir (mengikuti adat dan mengikuti makna yang tersembunyi) termasuk rusak (bathil). Klarisikasi ini, setidaknya dapat memberikan penjelasan kepada ulama bahwa istihan yang ditolak oleh Imam al-Syafi'i dan pengikutinya (termasuk alGhazali) adalah istihlsan bathil. Dengan demikian, istihsan dalam artian selain yang ketiga dan keempat yang dikemukakan oleh alKarkhi dan diuraikan oleh alGhazali, tidaklah tertolak dalam pandangan ulama Syafi'iyah.(Mubarok, 2002)

Dalam praktiknya, Imam Syafi'i disadari atau tidak sebetulnya menggunakan metode istihsan. Terdapat beberapa bukti sebagaimana diinformasikan oleh al-Razi bahwa dalam praktiknya Imam Syafi'i menggunakan istihsan. Misalnya menyangkut kasus mut'ah (pemberian suami) bagi istri yang diceraikan oleh suaminya, Imam Syafi'i mengatakan:

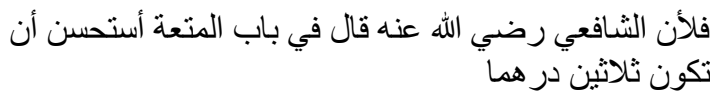

"Saya menganggap baik (lebih tepat) untuk menetapkan mut'ah pemberian suami bagi istri yang dicerai yang tidak memiliki anak sebesar tiga puluh dirham”.(Al-Razi, 1997)

Demikian pula dalam masalah muamalah, contoh praktik Imam Syafi'i menggunakan istih $\underline{\text { san }}$ berkenaan dengan kasus syuf'ah, Syafi'i menyatakan bahwa:

$$
\text { أستحسن أن يثبت للثفيع الثفعة إلى ثلاثة أيام }
$$

"Saya menganggap baik, jika orang yang memiliki kewenangan syuf'ah itu diberi waktu selama tiga hari”.(Al-Razi, 1997) 
Kedua contoh di atas, tentu merupakan butki bahwa dalam praktiknya Imam Syafi'i menggunakan metode istihsan. Begitu pula, banyak para ahli menyatakan bahwa pada dasarnya Syafi'i menggunakan istihsan dalam ijtihadnya. Mungkin sesekali Syafi'i, seperti dua contoh di atas, tidak menggunkan istihsan, tetapi pada praktiknya adalah istihsan. Jika demikian halnya, berarti antara Syafi'i yang menolak istihsan dengan kelompok yang menggunakannya sebagai hujah berbeda dalam mengartikan istihsan. Secara konseptual Syafi'i tidak memberikan formulasi istihsan, malah menokannya, tetapi dalam kegiatan ijtihadnya, secara tidak disadari, telah menggunakan istihsan sebagaimana dipraktikkan oleh kelompok yang menggunakan istihsan. Dengan demikian, secara konsep apa yang dinamakan istihsan itu diterima oleh Syafi'i, tetapi penamaan konsep itu dengan istihsan tidak diterimanya, karena pemakaian istilah tersebut cenderung mengacu kepada membuat-buat syara sendiri berdasarakan hawa nafsu (taladzuz).

Apabila diteliti persoalan yang menjadikan perbedaan pendapat di kalangan ulama ushul fikih dalam menerima atau menolak istihsan sebagai salah satu dalil syara', maka akan ditemu bahwa perbedaan tersebut hanyalah merupakan perbedaan istilah. Para ulama yang menolak keberadaan istihssan sebagai salah satu dalil dalam menetapkan hukum, ternyata dalam praktiknya berpendapat sama dengan ulama yang menerima kehujjahan istihsan. Dalam masalah akad mudhârabah dan hukum-hukum lain yang dikemukakan ulama yang menerima kehujjahan istihsan juga diterima oleh para penolak kehujjahan istiḩsan. Oleh sebab itu, Ibn Qudamah mengatakan bahwa tidak ada alasan untuk menolak istihsan apabila dilakukan berdasarkan dalil yang didukung oleh syara', sekalipun berdasarkan induksi dan berbagai ayat dan hadis. Adapun istihsan yang dilakukan semata-mata berdasarkan pendapat akal, maka seluruh ulama ushul fikih menolaknya, karena dalam masalah hukum syara' pendapat akal harus mendapat legalisasi dari nash, walaupun secara umum.(Khallaf, 2013)

Para ulama membagi istihsan kepada 6 (enam) macam, yaitu:

a. Istihsan bi al-Nash (istihsan berdasarkan ayat atau hadis). Maksudnya, ada ayat atau hadis tentang hukum suatu kasus yang berbeda dengan ketentuan kaidah umum. Dalam konteks transaksi muamalah, misalnya akad bai' (jual-beli) salam yang mana barang nya belum ada. Namun karena adanya nash dari hadis Nabi Saw yang membolehkan, maka jualbeli salam hukumnya adalah boleh.

Contoh lainnya adalah dalam masalah wasiat. Menurut ketentuan umum atau qiyâs wasiat itu tidak boleh, karena sifat pemindahan hak milik kepada orang yang berwasiat dilakukan ketika orang yang berwasiat tidak cakap lagi, yaitu setelah ia wafat. Tetapi kaidah umum ini dikecualikan melalui firman
Allah dalam surah al-Nisa (4) ayat 11. Berdasarkan ayat ini, kaidah umum tidak berlaku untuk masalah wasiat.

b. Istihlisan bi al-ijmấ' (istihsan yang didasarkan kepada ijmak). Dalam konteks muamalah, misal, ulama berijmak (sepakat) mengenai kebolehan melakukan akad ijârah atas pemandian umum meskipun terdapat unsur gharar mengenai jumlah air yang digunakan dan gharar pula jumlah air yang digunakan. Dan bolehnya istihhsan, secara qiyâs dilarang, namun sudah berjalan dimasyarakat tanpa adanya pengingkaran dari ulama (ijmak ulama bolehnya istihsan).

c. Istih̆han bi al-qiyâs al-khafiy (istihsan berdasarkan qiyas yang tersembunyi). Misalnya, dalam masalah wakaf lahan pertanian. Menurut ketentuan qiyâs jaliy (qiyas yang nyata), wakaf ini sama dengan akad jualbeli, karena pemilik lahan telah menggugurkan hak miliknya dengan memindah-tangankan lahan tersebut. Oleh sebab itu, hak orang lain untuk melewati tanah tersebut atau hak orang lain ntuk mengalirkan air ke lahan pertaniannya melalui tanah tersebut tidak termasuk akad wakaf itu, keciali jika di nyatakan dakan akad. Menurut qiyâs khafiy (qiyas yang tersembunyi) wakaf itu sama dengan sewamenyewa, karena maksud dari wakaf adalag memanfaatkan lahan pertanian yang diwakafkan. Dengan sifat ini maka seluruh hak orang lain yang telah ada di lahan pertanian tersebut, seperti hak melewati lahan pertanian itu atau hak mengalir air di atas lahan pertanian tersebut, termasuk ke dalam akad wakaf, sekalipun tidak dijelaskan dalam akad. Apabila seorang mujtahid mengambil hukum kedua (qiyâs khafiy), maka ia disebut berdalil dengan istihsan.(Ma'ruf Amin, 2008)

d. Istihlsan bi al-mashlahah (istihsan berdasarkan kemaslahatan). Dalam konteks muamalah, contohnya adalah ketentuan umum menetapkan bahwa buruh di suatu pablik tidak bertanggungjawab atas kerusakan hasil komoditi yang diproduk di pabrik tersebut, kecuali atas kelalian dan kesengajaan mereka, karena mereka hanya sebagai buruh yang menerima upah. Akan tetapi, demi kemaslahatan dalam memelihata harta orang lain dari sikap tidak bertanggungjawab para buruh dan silitnya mempercayai sebagian pekerja pabrik dalam masalah keamanan produk, maka ulama Hanafiyyah menggunakan istihssan dengan menyatakan bahwa buruh harus bertanggungjawab atas kerusakan setiap produk pabrik itu, baik disengaja maupun tidak.(Ma'ruf Amin, 2008)

Contoh lainnya adalah penerapan reveneu sharing pada profit distibution, sertapenerapan agunan dalam pembiayaan di bank syariah, salah satunya peneraoan agunan dalam akad-akad amanah seperti akad mudhârabah atau musyârakah. Secara asal akad ini tidak diperlukan adanya agunan, akan tetapi demi 
kemaslahatan maka diperbolehkan bagi bank syariah untuk menerapkan agunan dalam akad mudhârabah atau musyârakah.

e. Istihsan bi al-urf (istihsan berdasarkan adat kebiasan). Dengan kata lain yang dimaksud dengan istihsan bi al-'urf adalah suatu pengecualian hukum dari kaidah umum berdasarkan kebiasaan yang baik. Contoh dalam konteks muamalah adalah jual-beli mu'athah dilarang karena secara qiyas jual-beli ini tidak ada ijab-kabul. Akan tetapi karena sudah menjadi kebiasan di masyarakat maka hukumnya diperbolekan. Begitu pula jual-beli sharf secara sopt dengan masa dua hari. Contoh lainnya adalah kebiasaan masyarakat untuk menentukan jenis mata uang tertentu sebagai mata uang resmi suatu negara.

f. Istihsan bi al-Dharûrah (istihsan berdasarkan keadaan darurat). Artinya dibolehkan perbuatan yang dilarang karena kondisi darurat. Misalnya dibolehkannya melakukan Repo (Reouschase Agreemnt) surat berharga (SBI, SBSN) oleh bank syariah yang kesulitan likuiditas. Contoh lainnya adlaah dibolehkan menggunakan serta ikut serta sebagai anggota BJPS karena alasan darurat.

\section{Penerapan Motode Istiḩsan pada Bidang Mu'âmalah Mâliyyah (Hukum Ekonomi Syariah)}

Dalam konteks fikih muamalah perapan metode istihsan sangat diperlukan. Hal ini merupakan pengembangan yang sangat strategis. Hal ini dikarenakan metode istihsan memiliki daya kepekaan yang tinggi terhadap perubahan sosial masyarakat dalam kehidupan yang serba canggih dan cepat. Oleh karena itu, pembahasan ini menjadi fokus penerapan metode istihsan pada bidang muamalah maliyah. Adapun penerapan metode istiḩsan dalam bidang mu'âmalah maliyyah adalah sebagai berikut:

\section{Mempersyaratkan Hak Khiyâr bagi Orang Ketiga yang Tidak Ikut Berakad Jual-Beli (Bai')}

Para ulama bersepakat bahwa hak khiyâr (hak opsi untuk melanjutkan atau membatalkan transaksi) berlaku efektif bagi kedua belah pihak yang melakukan akad jual-beli (Bai'). Akan tetapi para ulama berbeda pendapat apakah bagi kedua belah pihak dipebrolehkan atau salah satu pihak mempersyaratkan adanya hak khiyâr bagi pihak ketiga yang tidak ikut serta dalam akad jual-beli.

Mazhab Hanafiyah, Malikiyah dan Syafi'iyah berpendapat bahwa mempersyaratkan hak khiyâr tersebut hukumnya adalah boleh dan persyaratan yang dinyatakan itu berlaku efektif.(Musthafa Dib al-Bugha, 2013)

Bagi kalangan Hanafiyah, dasan hukum hal tersebut adalah istiḩsan, yaitu istihssan bi al-mashlahah, dengan mempersyaratkan hak khiyâr tersebut menjadi hâjah (kebutuhan) dalam transaksi akad jual-beli yang berkembang di tengah-tengah kehidupan masyarakat.
Sedangkan bagi kalangan ulama Malikiyah dan Syafi'iyah, dasar hukum hal tersebut ialah qiyâs, yakni qiyâs yang nota bene substansinya sama dengan substansi istihsan di atas, tetapi mereka tidak menamakannya istihsan.

Kalangan ulama Hanafiyah berpendapat bahwa mempersyaratkan hak khiyâr tersebut tidak boleh dan persyaratan yang dinyatakan itu tidak sah. Mereka berargumen bahwa hak khiyâr merupakan konsekuensi dari adnaya akad jual-beli sehingga ia tidak berlaku efektif bagi orang yang tidak ikut serta dalam akad.

\section{Akad Jual-Beli dengan Mempersaratkan Pembayaran secara Tempo (Bai' al-Taqsîth/al-Ajâl)}

Bai' al-Taqsîth (jual-beli secara kredit) secara bahasa artinya membagi-bagi dan memisahmisahkannya menjadi beberapa bagian. Dalam kitab alMishbâh al-Munîr,(Muhammad 'Ali al-Alfayumi, 1987) dikatakan bahwa al-qisthu adalah al-nashîb yang artinya adalah bagian. Bentuk jamak (plural) adalah aqsâth. Begitu pula dalam kitab Lisân al-'Arab karya Ibn Mandzur,(Ibn Mandzur, 2013) disebutkan bahwa kata al-qisth maknanya adalah al-hishah wa al-nashib artinya porsi dan bagian.

Adapun definisi bai al-taqsith secara terminologis dikemukakan dalam kitab Majallat al-A $\underline{h} k \hat{a} m$ al'Adliyyah sebagai berikut:

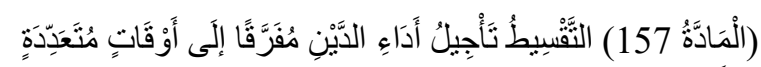

"Penangguhan pembayaran utang secara terpisah pada waktu yang telah ditentukan"(Lajnah Fukaha Khilafah Utsmaniyah, n.d.).

Dalam Fatwa Lajnah Dâimah li al-Buhûts al'Ilmiyyah wa al-Iftâ (Komite Tetap untuk Penelitian Ilmiah dan Fatwa Kerajaan Saudi Arabia) didefinisikan bai' al-taqsîth sebagai berikut:

$$
\text { متيع التقسيط هو: بيع السلعة بثمن مؤجل، يسدده على فترات }
$$

"Menjual barang dengan harga diangsur pada waktu yang telah ditentukan”.(Al-Iftâ, n.d.)

Pendapat lain mengatakan bahwa yang dimaksud dengan bai' al-taqsith adalah "Menjual sesuatu dengan pembayaran diangsur dengan cicilan tertentu, pada waktu tertentu, dan harga barang lebih mahal daripada pembayaran secara kontan".

Istilah bai' al-taqsith dalam khazanah fikih klasik belum dikenal oleh para ulama fikih klasik, akan tetapi mereka mengungkapkan dnegan istilah bai' al-ajâl (jualbeli tempo). Dengan demikian, dapat dikatakan bahwa bai' al-taqsith itu merupakan furû' (cabang) dari bai' alajâl, yaitu menjual barang dengan harga diangsur lebih mahal daripada kontan.(Hidayat, 2015) 
Apabila si A dan si B bersepakat untuk melakukan perjanjian akad jual-beli dan keduanya sepakat bahwa pembayaran harga dilakukan secara tempo, apakah akad itu sah dan persepakatan keduanya berlaku efektif.

Kalangan ulama Hanafiyah berpendapat bahwa akad jual-beli tersebut sah dan kesepakatan keduanya berlaku efektif. Mereka berargumen dengan dalil istihlsan, yakni istihsan dengan dasar pikiran menghilangkan kesukaran dan kesulitan jalannya kehidupan masyarakat, terutama di bidang perdagangan (istihsan bi al-mashlahah). Seiring dengan itum mereka menyatakan bahwa adanya tindakan mempersyaratkan pembayaran harga secara tempo merupakan bagian dari makna mempersyaratkan khiyâr).(Asnawi, 2013)

Kalangan ulama Syafi'iyah berpendapat bahwa akad jual-beli itu batal demi hukum dan kesepakatan keduanya juga batal, hal ini berimplikasi terhadap tidak efektifnya akad tersebut. mereka mereka, hal demikian bukanlah tindakan mempersyaratkan khiyâr, melainkan tindakan mempersyaratkan yang dapat merusak/membatalkan akad jual-beli itu karena hal demikian, sama saja dengan menggantunkan akad itu kepada sesuatu yang mengandung gharar (ketidakpastian/ketidakjelasan).(Musthafa Dib al-Bugha, 2013)

\section{Perihal Penerimaan Hibah Menguasai Barang Hibah Tanpa Seizin Pemberi Hibah}

Apabila si A memberikan hibah sebidang tanah kepada si B maka kapankah si B mempunyai hak atas tanah itu? Apakah saat si B mengcuapkan shîghat alqabûl ataukah pada saat ia menguasi tanah itu?

Kalangan ulama Malikiyah berpendapat bahwa si B mempunyai hak atas tanah itu pada saat ia mengcapkan shîghat al-qabûl dan sejak itu si A dapat dipaksa untuk atau harus menyerahkan tanah itu kepada si B. Mereka memandang tindakan penguasaan objek hibah $(a l-q a b d h)$ itu hanyalah merupakan unsur penyempurna akad hibah (syarth al-kamâl), bukan unsur kesahan (syarth al-shihâh ). Penerima hibah secara otomatis mempunyai hak atas objek hibah ketia ia telah mengucapkan shîghat al-qabûl.(Asnawi, 2013)

Kalangan ulama Hanafiyah, Syafi'iyah dan Hanabilah berpendapat bahwa si B mempunyai hak atas tanah itu pada saat ia telah mengucapkan shîghat alqabûl dan menguasai tanah itu.

Mereka memandang tindakan penguasaan objek hibah (al-qabdh) itu merupakan unsur kesahan (syarth al-shihhâh) akad hibah, bukan unsur penyempurna (syarth al-kamâl). Penerima hibah secara otomatis mempunyai hak atas objek hibah ketika ia telah mengucapkan shîghat al-qabûl dan menguasai objek hibah itu. Ketiga golongan ulama ini pun perbeda pendapat perihal tindakan penguasaan objek hibah oleh penerima hibah tanpa seizin penerima hibah.

Kalangan ulama Syafi'iyah dan Hanabilah memandang tidak sah penguasaan objek hibah itu kecuali dengan seizin permberi hibah, baik penguasaannya itu pada saat berakad maupun sedudahnya. Mereka berargumen dengan dalil qiyâs, yakni kasus tindakan penguasaan objek hibah oleh penerima hibah tanpa seizin pemberi hibah di-qiyâs-kan kepada kasus tindakan penguasaan objek jual-beli oleh pembeli tanpa membayar harganya terlebih dahulu kepada penjual, hal demikian tidak sah kecuali engan seizin penjual; dan illah-nya ialah penguasaan objek akad. Lagi pula, dalam kasus hibah, pada hakikatnya si pemberi hibah tidak berkewajiban menyerahkan objek hibah dan si penerima hibah tidak mempunyai hak atas objek hibah.

Kalangan ulama Hanafiyah menyatakan bahwa apabila penguasaan objek ( $a l$-qabdh) itu terjadi pada saat akad hibah maka hal demikian hukumnya boleh atau sah; namun, apabila terjadinya sesudah berlewatnya akad maka penguasaan objek $(a l$-qabdh) itu tidak boleh atau tidak sah kecuali dengan seizin pemberi hibah. Jadi, kalangan ulama Hanafiyah membedakan antara penguasaan objek hibah pada saat terjadinya akad dan penguasaan objek hibah sesudah berlewatnya akad. Dalam pendapatnya tersebut, mereka mengemukakan argumen berupa dalil istiḩsan. Dalam deskripsi istiḩsan dimaksud, mereka menjelaskan bahwa al-qabdh dalam akad hibah itu berfungsi sebagai ekspresi qabûl; dan alqabdh itu oenentu adanya hak/kepemilikan atas objek karena tujuan pokok hibah adalah memberikan kepemilikan. Maka menurut mereka, ijab dari pemberi hibah merupakan ekspresi penyerahan wewenang/hak keada penerima hibah untuk menguasai objek hibah; dan itu berarti izin secara implisit dari pemberi hibah. Adapun qaid "terjadi pada saat akad" didasarkan, menurut mereka pada pandangan bahwa ijab berhubungan secara kronologis dengan qabûl dan qabûl terikat dengan "saat terjadinya akad", begitu juga hanyalnya al-qabdh".(Musthafa Dib al-Bugha, 2013)

\section{Akad Syirkah Mufâwadhah}

Secara etimologis, syirkah ini dinamakan syirkah al-mufâwadhah karena adanya kesamaan dalam hal modal, profit, pengelolaan harta, dan lain sebagainya.(Adam, 2017) Adapun definisi syirkah almufâwadhah secara terminologis menurut Wahbah alZuhaili adalah:

$$
\begin{aligned}
& \text { وهي في الاصطلاح: أن يتعاقد اثنان فأكثر على أن يشتركا في عمل }
\end{aligned}
$$

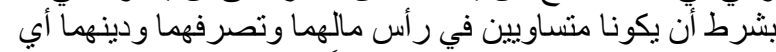

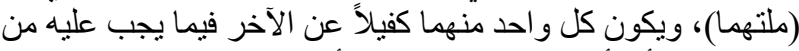

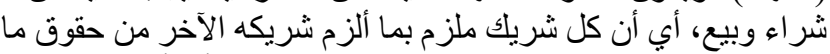

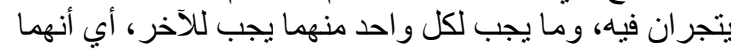

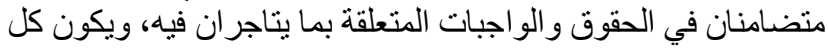

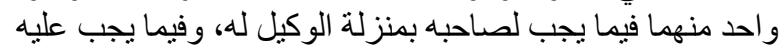

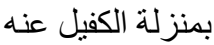

"Bentuk kejasama antara dua orang dalam suatu pekerjaan, dengan syarat keduanya sama dalam modal, pengelolaan harta dan agama, di mana 
masing-masing pihak menjadi penanggung jawab bagi yang lain dalam soal jual-beli. Dengan kata lain, masing-masing pihak terkait dengan transaksi yang dilakukan pihak lain baik dalam bentuk hak maupun kewajiban. Maksudnya, saling memberikan jaminan dalam hak dan kewajiban yang berkaitan dengan transaksi yang mereka lakukan. Dengan begitu, maisng-masing pihak menjadi wakil bagi mitranya untuk menrima hak, dan pada sat yang sama juga menjadi kafil (penanggung) atas kewajiban mirtanya".(Wahbah al-Zuhaili, 2012)

Para ulama berbeda berpendapat mengebai hukum kebolehannya. Ulama Hanafiyah berpedapat bahwa akad syirkah al-mufâwadhah hukumnya diperbolehkan yang didasarkan atas persamaan, baik dalam modal, keuntungan, keja, rugi dan agama segaiamana dijelaskan pada definisi di atas. Sedangkan ulama Syafi'iyah dan Hanabilah berpendapat bahwa hukumnya tidak sah (batal). Adapun ulama Malikiyah membolehkannya secara mutlak. Dengan kata lain tidak disyaratkan harus adanya persamaan sebagaimana yang dikemukakan oleh ulama Hanafiyah. Akan tetapi menurut ulama Malikiyah kebolehan akad syirkah al-mufâwadhah bukan seperti pendapat sebagaimana ulama Hanafiyah. Mereka memperbolehkan akad ini secara mutlak masing-masing yang berserikat mengelola modal tanpa harus membutuhkan pendapar rekan sekutunya.(Rasyid Hasan Khalil, 1981)

Dalam kitab al-Hidâyah sebagaimana dikutip oleh al-Bugha dijelaskan mengenai argumentasi ulama Hanafiyah yang membolehkan akad syirkah almufâwadhah sebagai berikut:

$$
\text { جائزة عندنا استحسانا الاستحسان, قال في الهداية: و هذه الثركة }
$$

"Landasan argumentasi kebolehan akad syirkah almufâwadhah berdasarkan istihssan. Dalam kitab alHidâyah disebutkan bahwa syirkah ini diperbolehkan menurut pandangan kami (mazhab Hanafi) berdasarkan istihsan”.(Musthafa Dib al-Bugha, 2013)

Selain berdasarkan istihsan, kebolehan akad syirkah al-mufâwadhah ini berdasarkan atsar dan interaksi kebiasaan. Adapun Atsar sebagaimana dimaksud adalah sebagai berikut:

$$
\text { فاوضوا فانه اعظم للبركة }
$$

"Samakanlah modal kalian, sebab hal tersebut lebih besar keberkahannya"

$$
\text { اذا فاوضنم فاحسنو المفاوضة }
$$

"Apabila kalian melakukan bisnis dengan akad kerjasama musfâwadhah maka baguskanlah modal kalian".
Di dalam kitab al-Fath sebagaimana dikutip oleh al-Bugha disebutkan bahwa hadis ini tidak dikenal dalam kitab-kitab hadis, wallahu'Alam, maka atsar tersebut tidak dapat dijadikan landasan argumentasi.

Adapun landasan berdasarkan 'urf atau kebiasaan orang-orang yang mempraktikan akad syirkah almufâwadhah tanpa ada yang mengingkarinya, maka kebiasaan tersebut seperti ijmak/konsensus maka dengan ini ditinggalkan qiyâs. Apabila riwayat atsar tersebut dinilai lemah dan tidak dapat dijadikan landasan argumentasi (untuk kebolehan akad syirkah almufâwadhah) maka argumennya dikembalikan kepada istihsan dan kebiasaan/urf. Ini adalah bentuk istihsan li al-'urf atau kebiasan menurut mazhab Hanafi atau istihsan bi al-ijmâ.(Musthafa Dib al-Bugha, 2013)

\section{Akad Jual-Beli Istishna'}

Kata istishna' berasal dari kata shana'a yang sama dengan kata ja'ala atau khalaqa yang secara harfiah berarti membuat atau menciptakan. Akad jualbeli istishna' pada prinsipnya sama dengan akad jualbeli salam, yaitu merupakan pengecualian dari syarat jual-beli yang berlaku umum, wujudnya objek akad pada saat akad jual-beli dialukan.(Jaih Mubarok dan Hasanudin, 2017)

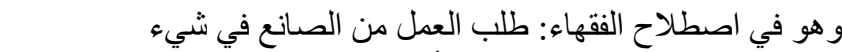

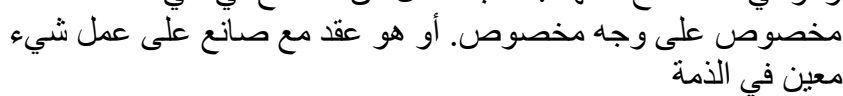
memberikan definisi istishna' sebagai berikut:

"Akad meminta seseotang untuk membuatkan sebuah barang tertentu dalam bentuk tertentu, atau dapat diartikan sebagai akad yang dilakukan oleh seseorang untuk membuat barang tertentu dalam tanggungan".(Wahbah al-Zuhaili, 2012)

Kalangan ulama Hanafiyah berpendapat bahwa jika didasarkan pada qiyâs dan kaidah umum, maka akad istishna' tidak boleh dilakukan, karena akad ini mengandung jual-beli barang yang tidak ada (bai' ma'dûm) seperti akad salam. Jual-beli barang yang tidak ada tidak dibolehkan berdasarkan larangan Nabi Saw untuk menjual sesuai yang tidak dimiliki oleh seseorang. Oleh karena itu, akad ini tidak dapat dikatakan sebagai jual-beli, karena merupakan jual-beli barang yang tidak ada.

Bagi ulama Hanafiyah bahwa akad istishna' boleh dilakukan berdasarkan dalil istihlsan yang ditunjukan dengan kebiasaan masyarakat melakukan akad ini sepanjang masa tanpa ada yang mengingkarinya, sehingga menjadi sebuah konsensus/ijmak tanpa ada yang menolaknya. Menggunakan konsep dalil seperti ini masuk dalam makna hadis, "umatku tidak akan bersepakat dalam kesesatan" dan hadis "apa yang dianggap baik oleh kaum muslimin maka dia adalah baik menurut Allah”.(Wahbah al-Zuhaili, 2012) 


\section{Mensedekahkan Seluruh Harta dan Tidak Berniat untuk Berzakat}

Para ulama sepakat bahwa tidak boleh menunaikan zakat kecuali harus disertai niat untuk menunaikan kewajibanya berupa mengerluarkan sebagian hartanya (tertentunya) dan menyerahkannya kepada mustahiqnya. Akan tetapi para ulama berbeda pendapat bagi orang yang terkena kewajiban zakat ia menyedekahkan seluruh hartanya akan tetapi tidak disertai niat membayar zakat, apakah kewajiban zakatnya gugur atau tetap adanya kewajiban berzakat?

Imam Syafi'i dan Ahmad berpendapat bahwa kewajiban zakat tidak gugur, Imam Nawawi dalam kitab al-Majmu' sebagaimana dikutip oleh al-Bugha berpendapat sebagai berikut:

$$
\text { خلاف. لصدق بجميع ماله, ولم ينوى الزكاة, لم تسقط عنه الزكاة بلا }
$$

"Apabila ia menyedekahkan seluruh hartanya dan tidak disertai niat untuk menunaikan zakat, maka kewajiban zakat tidak gugur dan tidak ada perbedaan pendapat dalam hal ini'.(Musthafa Dib al-Bugha, 2013)

Lebih lanjut al-Bugha mengutip pendapat Ibn Qudamah dalam kitab al-Mughni sebagai berikut:

$$
\text { لو تجئه. }
$$

"Apabila seseorang menyedekahkan seluruh hartanya secara tathawu (sunah) dan tidak berniat zakat maka tidak bisa dikatakan zakat”.

Abu Hanifah dan para pengikutnya berpendapat bahwa zakat tersebut gugur. Dalam kitab al-Hidâyah sebagaimana dikutip oleh al-Bugha disebutkan bahwa siapa yang mensedekahkan seluruh hartanya, tidak diringi niat untuk berzakat, maka kewajiban zakat terseut gugur. Dasar argumentasi mazhab Hanafi bahwa kewajiban zakat gugur adalah berdasarkan istihan karena apabila berdasarkan qiyâs kepada shalat yang harus ditegaskan niatnya maka kewajiban tidak tidak akan gugur, kana hukum yang sunah dan wajib keduanya sama-sama disyariatkan.(Musthafa Dib al-Bugha, 2013) Dengan demikian menurut Hanafi berdasarkan istihsan mensedekahkan seluruh harta tanpa disertai niat maka kewajiban zakat adalah gugur.

\section{Masalah Zakat Kontemporer}

Istihsan digunakan oleh sekelompok ulama karena dalam menghadapi suatu kasus pada keadaan tertentu merasa kurang puas jika menggunakan pendekatan yang berkalu secara konvensional, seperti dengan menggunakan qiyâs jaly atau dalil umum menurut caracara biasa dilakkan. Dengan cara konvensional itu, ketentuan ukum yang dihasilkan kuramh (tidak) mendatangkan kemaslahatan yang diharapkan dari penetapan hukum. Dalam keadaan demikian, si mujtahid menggunakan dalil atau pendekatan lain sebagai alternatif (penggati) dari penedekatan yang konvensional tersebut. pendekatan tersebut disebut dengan istihsan.

Dewasa ini dan lebih-lebih lagi pada masa yang akan datang permasalahan kehidupan manusia akan semakin berkembang dan semakin kompleks. Permasalahan itu harus dihadapi umat Islam yang menuntut adanya jawaban penyelesaiannya dari segi hukum Islam. Apabila hanya semeta mengandalkan pendekatan dengan cara atau metode lama (konvensional) yang digunakan ulama terdahulu untuk menghadapinya, mungkin tidak mampu menyelesaikan semua permasalahan tersebut dengan baik (tepat). Karena itu, si mujtahid harus mempu menemukan pendekatan atau dalil alternatif di luar pendekatan lama, meskipun dengan berat hati untuk meninggalkan pendekatan lama yang selaa ini ia gunakan dan ia pertahankan dengan setia. Oleh kerana itu, kecenderungan untuk mengguakan istihsan akan semakin kuat karena kuatnya dorongan dari tantangan persoalan hukum yang berkembang dalam kehidupan manusia yang semakin cepat berkembang dan semakin kompleks.(Amir Syarifuddin, 2011)

Salah satu contoh yang paling dekat dan mendesak untuk ditangani dari persoalan kehidupan dewasan ini adalah masalah zakat. Dalil syara' yang dikemukakan dalam kitab-kitab fikih yang ada kebanyakan berbicara dalam kaitan dengan sektor pertanian dan sedikit sekali yang berkenaan dengan jasa dan produksi. Padahal dewasa ini perkembangan sektor jasa dan produksi itulah yang berkembang dengan pesat dan lebih dominan dibanding sektor pertanian yang semakin langka. Kalau dalam menghadapi kehidupan ekonomi dewasa ini dan di masa mendatang khususnya yang menyangkut masalah zakat, hanya mengandalkan pendekatan lama dalam merumuskan ketentuan hukumnya, maka tidak akan memadai lagi. Dalam menghadapi masalah ekonomi, jika menggunakan ketentuan lama tentang zakat, maka zakat tidak akan berkembang karena sektor pertanian semakin langka, sedangkan pihak yang mengaharapkan bantuan melalui penghimpunan dana sosial melalui zakat semakin banyak. Katakanlah umpamanya "zakat profesi" . kalau masih berkutat dengan pendekatan dan dalil konvensional yang selama ini digunakan, masalahnya tetap tidak akan terselesaikan. Karena itu diperlukan upaya untuk mencari alternatif pendekatan lain untuk menyelesaikannya. Upamanya berdalil dengan umumnya lafadz "ma kasabtum" yang terdapat dalam Alquran surah al-Baqraah (2) ayat 264. Dalam ayat tersebut sektor jasa dan profesi secara jelas terkandung di dalamnya.(Amir Syarifuddin, 2011)

\section{Tawarruq Multiguna untuk Pembiayaan Produktif}

Pembiayaan multiguna dapat menggunakan skim tawarruq emas atau bai' al-wafâ wa al-ijârah yang 
disebut dengan akad bai' al-istighlâl. Secara etimologis, al-tawarruq adalah bentuk mashdar dari kata tawarraqa. Dikatakan الحيوان تورق (binatang itu memakan daun). ألْوَرَقُ dikasrahkan ra-nya artinya dirham yang dicetak dari perak. Menurut sebagian riwayat artinya perak yang dicetak atau tidak dicetak.(Hidayat, 2015)

Kata al-tawarruq diartikan daun maksudnya adalah memperbanyak harta. Dengan demikian altawarruq diartikan sebagai kegiatan memperbanyak uang.(Abd al-Rahman al-Sa'di, 2008) Dalam kajian literatur al-tawarruq adalah berbagai cara yang ditempuh seseorang demi mendapatkan uang tunai. Adapun definisi al-tawarruq secara terminologi adalah:

$$
\text { ليحصل بذترى سلعة نسيئة ثم يبيعها لغير البائع باقل مما اشتر اها به }
$$

"Seseorang yang membeli barang dagangan secara tidak tunai (diangsur), kemudian ia (pembeli) menjualnya kepad orang lain selain penjual secara tunai (cash) dengan harga yang lebih murah daripada harga pembelian, tujuannya untuk memperoleh uang tunai (cash) (bukan dalam bentuk barang"(Hidayat, 2015)

Definisi lain menyebutkan bahwa al-tawarruq adalah seseorang yang membutuhkan uang tunai kemudian membeli suatu barang dengan cara kredit, dan menjualnya kepada pihak ketiga dengan harga yang lebih murah dari harga aslinya secara tunai.(Muhamad Nadratuzzaman, 2013)

Adapun bai' al-istighlâl yang terdapat dalam kitab Majallah al-A $\underline{h} k \hat{a}$ al- 'Adliyyah (Hukum Perdata Islam) Pasal 119 Qanun Turki 1876 H. Dalam Pasal 119 tesebut bai al-istighlâl didefinisikan sebagai berikut:

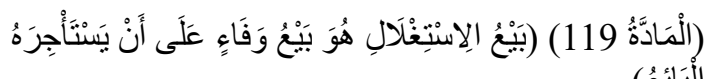

“ Bai' al-istighlâl adalah jual-beli wafâ yang mana pembeli menyewakan kembali barang yang dibelinya kepada penjual”.

Jual-beli istighâl pada prinsipnya merupakan hubungan konsep jual-beli wafâ dengan konsep ijârah (sewa-menyewa), yakni pemanfaatan objek-jual beli dengan cara disewa atau disewakan. Dengan kata lain, barang yang sudah dijual kepada pembeli, diseakan kembali oleh pembeli kepada penjual.

Dalam perspektif mazhab Hanafi, akad bai' alistighlâl merupakan akad yang sah dan diperbolehkan.('Utsmani, 2005) Adapun menurut Rafiq Yunus al-Mishri akad bai' al-istighlâl merupakan akad yang terlarang. Rafiq Yunus al-Mishri menyatakan bahwa:

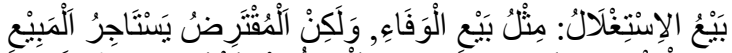

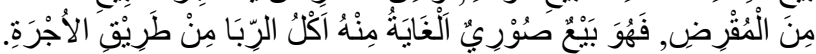

'Jual-beli istighlâl mirip dengan bai' al-wafâ, akan tetapi (perbedaannya) adalah muqtaridh (debitur dalam akad qardh/utang-piutang (penjual pada akad jual-beli pertama) menyewa barang yang dijualnya dari muqridh (kreditur dalam akad qardh (pembeli pada akad jual-beli pertama); maka jual-beli istighlâl termasuk akad jual-beli shûry (artifisial) karena tujuan pembeli (dalam akad jual-beli pertama) adalah untuk mencarii profit (transaksi riba) dengan cara sewa".(Rafiq Yunus al-Mishri, 2009)

Skim tawarruq emas ini diambil dari banyak buku fikih, terutama buku, tawarruq mashrafi an tharîq alma'adin (tawarruq di perbankan melalui jual-beli emas). Mayoritas ulama fikih menyetujui bai' tawarruq, namun Umar Ibn Abd al-Aziz, Ibn Taimiyyah, dan Ibn Qayyim al-Jauziyyah berpandangan makruh hukumnya. Fatwa ulama OKI hanya mengharamkan tawarruq munazzam yang banyak dilakukan sebagian bank syariah Malaysia. Tawarruq munazzam ini tidak lain adalah bai' al- 'inah itu sendiri, maka hukumnya dilarang.(Mohammmad Mufid, 2016)

Kalau berpegang pada pendapat mayoritas ulama, maka penerapan tawarruq, tidak bermasalah. Namun, jika berpegang pada pendapat Umar Ibn Abd al-Aziz, Ibn Taimiyyah, dan Ibn Qayyim al-Jauziyyah, yang kemakruhannya, maka hal itu dapat dihilangkan dengan metode istihssan. Jika menggunakan metode istihsan, maka harus bisa ditunjukkkan bahwa tawarruq yang hendak diterapkan di perbankan, harus berbeda karakternya dengan tawarruq yang dimakruhkan, oleh sebagian ulama itu. Pada tawarruq perbankan itu, harus ada syarat ketat dari bank syariah, yakni bahwa dana tawarruq harus digunakan untuk sektor riil (yang produktif) dan officer perbankan harus mengontrol kebenaran terwujudnya sektor riil di lapangan.(Mohammmad Mufid, 2016)

Jadi, untuk mewujudkan itu officer bank syariah dlaam visibility study dan analisa pembiayaan harus mensyaratkan bahwa penggunaan uang tawarruq memang untuk sektor riil, seperti usaha mikro, pertanian dan kegiatan usaha produktif lainnya, atau semi produktif seperti pendidikan, renovasi rumah, dan sebagainya. Multiguna artinya penggunaan uang tersebut dapat digunakan untuk apa saja, asalkan untuk sektor riil yang sesuai syariah.

Bai al-wafâ dan bai al-istighlâl juga dapat digunakan untuk pembiayaan multiguna. Mekanismenya, pertama, nasabah menjual asetnya (rumah, perkebunan, atau mobil), ke bank syariah dengan harga misalkan Rp. 200 juta, dengan janji nasabah akan membeli (melunasi) kembali rumah tersebut 2 tahun depan dengan harga yang sama, yakni Rp. 200 juta. Dengan jual-beli ini, nasabah mendapatkan uang cash dari bank dan dengan demikian rumah menjadi milik bank. Kedua, selanjutnya, bank 
menyewakan rumah itu kepada nasabah itu kembali dengan margin tertenu.(Agustianto, 2014)

Bank mendapatkan keuntungan (margin) dengan cara penyewaan tersebut. besaran biaya sewa bulanan dapat memilih dua alternatif, pertama, biaya sewa bulanan dari margin disesuaikan dengan besaran cicilan normal pembiayaan, misalnya Rp. 10 juta per-bulan. Ketika masa sewa (dengan akad ijârah) selesai, maka rumah itu kembali dijual bank kepada nasbaha dengan harga tertentu. Pilihan kedua, dalam perjanjan itu disyaratkan nasabah untuk menyimpan sejumlah dana setiap bulannya misalkan Rp. 9,1 juta dan ketika jumlah simpanan mencapai Rp. 200 juta, maka janji nasabah untuk membeli kembali rumah tersebut diwujudkan. Syarat tersebut tidak dilarang dalam syariah, karena itu ia dibolehkan.(Agustianto, 2014)

\section{SIMPULAN}

Dengan demikian dapat disimpulkan bahwa istihsan merupakan salah satu metode istinbâth alahkâm, yang dapat dijadikan hujjah dan menjadi dalil syara'. istihsan memiliki peran yang menentukan dalam fikih Hanafi dan Maliki, karena banyak hal yang telah diselesaikan dengan istihsan dan telah ditetakan hukumnya. Adapun penolakan Imam Syafi'i terhadap

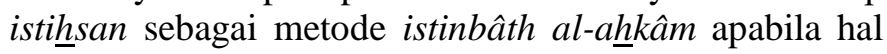
tersebut dilakukan dengan hawa nafsu dan mencari kelezatan semata (taladzuz). Penerapan metode istihsan dalam bidang mu'âmalah mâliyyah berdasarkan hasil penelitian penulis dapat terimplemnetasikan pada 8 akad diantaranya adalah (a) Mempersyaratkan Hak Khiyâr bagi Orang Ketiga yang Tidak Ikut Berakad Jual-Beli (Bai'); (b) Akad Jual-Beli dengan Mempersaratkan Pembayaran secara Tempo (Bai' al-Taqsîth/al-Ajâl); (c) Perihal Penerimaan Hibah Menguasai Barang Hibah Tanpa Seizin Pemberi Hibah; (d) Akad Syirkah Mufâwadhah; (e) Akad Jual-Beli Istishna'; (f) Mensedekahkan Seluruh Harta dan Tidak Berniat untuk Berzakat; (g) Masalah Zakat Kontemporer; (h) Tawarruq Multiguna untuk Pembiayaan Produktif.

\section{DAFTAR PUSTAKA}

'Utsmani, M. T. (2005). Fiqh al-Buyû 'Alâ al-Madzâhib al-Arba'ah Ma'a Tahtbîqatihi al-Mu'ashîrah Muqâran (an) bi al-Qawânin al-Wadh'î. Maktabah Ma'arif al-Qur'an.

Abd al-Rahman al-Sa'di. (2008). Fiqih Jual Beli: Panduang Praktis Bisnis Syariah. Senayan.

Abu Hamid al-Ghazali. (1989). al-Mankhûl Min Ta'lîqât al-Ushûl. Dâr al-Fikr al-Mu'âshir.

Adam, P. (2017). Fikih Muâmalah Mâliyah: Konsep, Regulasi dan Implementasi. Refika Aditama.

Adi, R. (2004). Metode Penelitian Sosial dan Hukum. Granit.

Agustianto. (2014). Reaktualisasi dan Kontekstualisasi Fikih Muamalah Ke-Indoneisaaan: Upaya Inovasi Produk Perbankan dan Keuangan Syariah.
Iqtishad Publishing.

Al-Iftâ, L. D. li al-B. al-'Ilmiyyah wa. (n.d.). Fatâwâ alLajnah al-Dâimah. Riasah Idarah al-Buhuts al'Ilmiyyah wa al-Ifta.

Al-Razi, F. al-D. (1997). al-Mahshûl. Muasasah alRisalah.

Ali Hasab Allah. (1971). Ushûl al-Tasyrî’ al-Islamâmî. Dar al-Ma'arif.

Amir Syarifuddin. (2011). Ushul Fiqh 2. Kencana Prenada Media Group.

Asnawi. (2013). Perbandingan Ushul Fiqh. Amzah.

Bakhtiar Hasan. (2015). Penolakan Imam Syafi'i Terhadap Istihsan Sebagai Salah Satu Methode Istinbath Hukum Islam. Al-Risalah, 15(1), 59.

Beik, M. al-K. (2003). Ushûl al-Fiqh. Dâr al-Hadîts.

Chadzik, A. L. (2019). Istihsan dan Implementasinya dalam Penetapan Hukum Islam. MIYAH: Jurnal Studi Islam, 15(02), 338.

Habibullah, E. S. (2017). Al Mashlahah Jurnal Hukum Dan Pranata Sosial Islam Pandangan Imam Abu Hanifah Dan Imam Syafi' I Tentang Al-Istihsan. Al Mashlahah Jurnal Hukum Dan Pranata Sosial Islam, 4(7), 456.

Hanbal, A. I. (2001). al-Musnad. Muasasah al-Risalah.

Hidayat, E. (2015). Fiqh Jual Beli. Rosdakarya.

Ibn Mandzur. (2013). Lisân al- 'Arab. Dâr al-Hadîts.

Jaih Mubarok dan Hasanudin. (2017). Fikih Mu'alamah Maliyyah: Akad Jual-Beli. Simbiosa.

Kadenun. (2018). Istihsan sebagai Sumber dan Metode Hukum Islam. Qalamuna, 10(2), 101.

Khallaf, A. al-W. (2013). Mashâr al-Tasyrî̀ al-Islâmî fima Lâ Nash Fîh. Dâr Ibn al-Jauzi.

Lajnah Fukaha Khilafah Utsmaniyah. (n.d.). Majallat alAhkâm al- 'Adliyyah. Nur Muhammad.

Ma'ruf Amin. (2008). Fatwa Dalam Sistem Hukum Islam. Elsas.

Mohammmad Mufid. (2016). Ushul Fiqh Ekonomi Dan Keuangan Kontemporer: Dari Teori ke Aplikasi. Kencana Prenada Media Group.

Mubarok, J. (2002). Metodologi Ijtihad Hukum Islam. UII Press.

Muhamad Nadratuzzaman. (2013). Produk Keuagan Islam di Indonesia dan Malaysia. Kompas Gramedia.

Muhammad 'Ali al-Alfayumi. (1987). al-Mishbâh alMunîr. Maktabah Libanon.

Muhammad Abu Zahrah. (n.d.). Ushûl al-Fiqh. Dar alFikr al-'Arabi.

Muhammad Ibn Idris al-Syafi'i. (1940). al-Risâlah. Maktabah al-Halabi.

Musthafa Dib al-Bugha. (2013). Atsar al-Adillah alMukhtalaf Fîha: Mashâdir al-Tasyrî al-Tabi'iyyah fi al-Fiqh al-Islâmî. Dâr al-Qalam.

Nur'aini, A. M. M. (2020). Istihsan Sebagai Metode Istimbath Hukum Imam Hanafi Dan Relevansinya Dalam Pengembangan Ekonomi Syariah. Tribakti: Jurnal Pemikiran Keislaman, 31(1), 3. 
Rafiq Yunus al-Mishri. (2009). Buhûts fi Fiqh alMu'âmalât al-Mâliyyah. Dar al-Maktabi.

Rasyid Hasan Khalil. (1981). al-Syirkât fì al-Fiqh alIslâmî: Dirâsah Muqâranah. Dar al-Rasyid.

Romli. (1999). Muqaranah MAzahib fil Ushul. Gaya Media Pratama.

Soerjono Soekanto \& Sri Mamudji. (1985). Penelitian Hukum Normatif (Suatu Tinjauan Singkat). Rajawali Pers.

Syawaluddin Hanafi. (2020). Urgensi Pemikiran Syams Al-Aimmah Al-Syarakhsi Tentang Al-Istihsan Dalam Menjawab Problematika Hukum Dalam Masyarakat. Tasamuh: Jurnal Studi Islam, 12(2), 340.

Wahbah al-Zuhaili. (2006). Ushûl al-Fiqh al-Islâmî. Dâr al-Fikr.

Wahbah al-Zuhaili. (2012). al-Fiqh al-Isâmî wa Adillatuh. Dar al-Fikr.

Zaky al-Din Sya'ban. (1965). Ushûl al-Fiqh al-Islâmî. Dar al-Ta'lif.

Zulbaidah. (2016). Ushul Fiqh 1: Kaidah-Kaidah Tasyri'iyah. Ghalia Indonesia. 